\title{
Boreal tree species affect soil organic matter composition and saprotrophic mineralization rates
}

\author{
Javier H. Segura $(\mathbb{D} \cdot$ Mats B. Nilsson • Tobias Sparrman • \\ Henrik Serk • Jürgen Schleucher • Julie Tolu • Mats G. Öquist
}

Received: 19 December 2018 / Accepted: 24 April 2019 / Published online: 24 May 2019

(C) The Author(s) 2019

\begin{abstract}
Aims To investigate how different tree species affect the composition of SOM and its mineralization in boreal forest ecosystems.

Methods We used pyrolysis GC-MS for molecularlevel characterization of the SOM formed under five common boreal tree species at a replicated field experiment $\sim 50$ years after plantation. We incubated soil samples at $4,9,14$ and $19^{\circ} \mathrm{C}$ and measured inherent $\mathrm{CO}_{2}$ production and substrate-induced respiration. We then evaluated if the saprotrophic microbial activity and its
\end{abstract}

Responsible Editor: Ingrid Koegel-Knabner.

Electronic supplementary material The online version of this article (https://doi.org/10.1007/s11104-019-04105-x) contains supplementary material, which is available to authorized users.

J. H. Segura $(\bowtie) \cdot$ M. B. Nilsson · M. G. Öquist

Department of Forest Ecology \& Management, Swedish

University of Agricultural Sciences (SLU), Skogsmarksgränd,

SE-901 83 Umeå, Sweden

e-mail: javier.segura@slu.se

T. Sparrman

Department of Chemistry, Umeå University, SE-901 87 Umeå,

Sweden

H. Serk · J. Schleucher

Department of Medical Biochemistry and Biophysics, Umeå

University, SE-901 87 Umeå, Sweden

J. Tolu

Department of Ecology and Environmental Science, Umeå

University, SE-901 87 Umeå, Sweden temperature sensitivity was controlled by the SOM composition.

Results The molecular composition of the SOM emerged as key factor influencing SOM properties in plots with different tree species. Most of the variance in the SOM content was explained by the organo-chemical composition of the SOM. More importantly, the fraction of the microbial community able to utilize the native SOM was largely controlled by the SOM organochemical composition. Temperature sensitivity of $\mathrm{CO}_{2}$ production $\left(\mathrm{Q}_{10}\right)$ was not explained by SOM composition. However, the microbial access to different SOM pools varied with temperature.

Conclusions These results bridge the gap between the paradigms of short-term litter and long-term SOM decomposition showing that, on an intermediate timescale ( $\sim 50$ years), boreal tree species affect SOM molecular composition and saprotrophic mineralization rates.

Keywords Boreal forest - Soil organic matter · Organochemical composition $\cdot$ Microbial respiration $\cdot \mathrm{Q}_{10} \cdot \mathrm{Q}_{\mathrm{R}}$. Pyrolysis-GC-MS

\section{Introduction}

An estimated $30 \%$ of the earth's soil organic matter (SOM) pool of ca. $2300 \mathrm{Pg} \mathrm{C}$ is stored in soils of high-latitude ecosystems (Tarnocai et al. 2009). This mass of carbon is similar to that of $\mathrm{CO}_{2}-\mathrm{C}$ presently found in the atmosphere (Ciais et al. 2014). Therefore, 
even small changes in the rate of SOM decomposition in these regions can profoundly affect atmospheric $\mathrm{CO}_{2}$ levels and the global climate. Soil $\mathrm{C}$ cycling in highlatitude boreal forests is expected to change in the coming years because of increasing warming (mainly during winter), changes in the water balance, and land use intensification (Hyvönen et al. 2007; Ciais et al. 2014). It is therefore necessary to better understand how land management activities such as the choice of forestry tree species impact terrestrial ecosystem processes and their sensitivity to changing environmental conditions.

The composition of SOM and its turnover are critical determinants of nutrient cycling, soil formation, and the net ecosystem carbon balance (Waksman 1936; Trumbore 2000; Kleber and Johnson 2010; Schmidt et al. 2011). However, the interaction between the composition and decomposition of SOM is not fully understood because of the challenges associated with characterizing the genesis and decomposition rate of SOM, and the associated biological processes (Lehmann and Kleber 2015). SOM is currently believed to consist of a complex continuum of plant and microbial biopolymers and their degradation products in a state of progressive biotic and abiotic decomposition (Sutton and Sposito 2005; Kelleher and Simpson 2006; Schmidt et al. 2011; Lehmann and Kleber 2015). The persistence of SOM in the soil thus depends on a complex set of interactions between biological and physicochemical factors that control its rate of decomposition (Schmidt et al. 2011).

Important abiotic drivers of SOM decomposition include the soil moisture and soil temperature, both of which strongly affect rates of saprotrophic microbial activity. The Arrhenius kinetic model (Arrhenius 1889) suggests that the temperature sensitivity of a reaction's rate should increase as a consequence of decreased activation energy (i.e. higher carbon quality). However, in practice it is difficult to determine exactly how the decomposition of SOM depends on the temperature. This is largely due to the multitude of processes involved and the fact that the overall response depends on a wide range of environmental factors aside from the temperature, as well as substrate availability (Davidson and Janssens 2006; Ågren and Wetterstedt 2007; Öquist et al. 2009, 2016). It has been suggested that the organochemical composition of the SOM controls microbial access to the substrate and must therefore be accounted for when attempting to understand the temperature response of SOM decomposition (Conant et al. 2011; Erhagen et al. 2015).
The organo-chemical composition of SOM is highly sensitive to the plant species growing in the soil and their traits because they are major sources of SOM. In particular, the presence of different tree species can profoundly affect the composition of the SOM (Preston et al. 2000; Quideau et al. 2001; Erhagen et al. 2013). The rate and temperature sensitivity of SOM decomposition are also influenced by the tree species that dominate the organic matter input to the soil (Karhu et al. 2010; Erhagen et al. 2013). It has been suggested that the influence of tree species on the physicochemical properties of the soil and biogeochemical processes is primarily observed in the superficial topsoil (Augusto et al. 2015 and references therein). The variation in edaphic factors and land-use history often makes it difficult to evaluate the effects of individual tree species on soil properties and processes in established forests. Common garden tree replication experiments eliminate some of these site-related factors that confound assessments of species' effects (Binkley 1995; Hobbie et al. 2006; Mueller et al. 2015) but are rarely performed (Augusto et al. 2015).

Common garden studies in the boreal region are scarce but those available have reported significant differences in the forest topsoil $\mathrm{C}$ stocks among tree species, i.e. more $\mathrm{C}$ is found in Picea and Pinus plots compared to broadleaves after ca 35 years (Alban 1982; Smolander et al. 2005) and $>50$ years (Olsson et al. 2012) after tree establishment. In contrast, Alriksson and Eriksson (1998 and 2001) found no significant differences in topsoil $\mathrm{C}$ stocks among tree species ca 30 years after tree planting but do report differences in the distribution of micronutrients in the soil and vegetation compartments. However, it is not clear from these studies how SOM formation and degradation are affected by changes in tree species composition over intermediate time scales ( $\sim 50$ years) caused by e.g. afforestation or environmental change. This is partly because the diversity of molecular structures originating from the litter of trees involved in SOM formation and further microbial processing involved in the long-term stability of SOM cannot be fully represented by coarse metrics as $\mathrm{C}: \mathrm{N}$ ratios.

To bridge this knowledge gap, the aim of this study was to determine how different tree species affect soil properties and processes critical for SOM composition and its mineralization in boreal forest ecosystems. We hypothesized that, different tree species generate SOM with different organo-chemical compositions, leading to 
differences in the mineralization, $\mathrm{CO}_{2}$ production temperature response, and SOM properties. To test this hypothesis, we investigated the molecular composition of SOM developed on the topsoil of a ca. 50-year-old replicated tree plantation experiment featuring five commonly occurring boreal tree species.

\section{Material and methods}

Site description and experimental design

SOM was collected from an experimental site located $15 \mathrm{~km}$ north of Umeå in N.E. Sweden $\left(63^{\circ} 53^{\prime} 42^{\prime \prime}\right.$, $\left.20^{\circ} 32^{\prime} 34^{\prime \prime} \mathrm{E}\right)$. Over the standard climate reference period of 1961-1990, the annual mean temperature at the site was $2.9^{\circ} \mathrm{C}$ and the annual precipitation was $662 \mathrm{~mm}$ (Alexandersson et al. 1991). The site was planted according to a randomized block experimental design featuring three replicate $25 \times 25 \mathrm{~m}$ plots of meadow (used as control plots) and the five different tree species: Norway spruce (Picea abies L. Karst.), Lodgepole pine (Pinus contorta Dougl.), Scots pine (Pinus sylvestris L.), Siberian larch (Larix sibirica Ledeb.) and Silver birch (Betula pendula Roth). The land at the site was formerly cultivated; its soil is an Inceptisol originating from glacifluvium with a silty layer overlaying clay (Soil Survey Staff 2003). The soils at the site were ploughed and fertilized until the late 1940s. It was used as a hay meadow during the $1950 \mathrm{~s}$, and was subsequently left unused until the establishment of the tree species experiment. Seedlings were germinated in 1968 and planted in 1971 without site preparation. Mechanical weed control was applied once a year for the first 8 years after tree plantation ( 90 seedlings per plot). The total stem basal area measured in 1998 was $28,32,32,25$ and $27 \mathrm{~m}^{2} \mathrm{ha}^{-1}$ for B. pendula, L. sibirica, P. abies, P. contorta and $P$. sylvestris, respectively (Alriksson and Eriksson 1998). At the time of sampling for this study, stem basal area amounted to 25, 26, 31, 20 and 26 $\mathrm{m}^{2} \mathrm{~h}^{-1}$ for $B$. pendula, L. sibirica, P. abies, P. contorta and $P$. sylvestris, respectively. The reduction in stem basal area was due to commercial thinnings for all species except for $P$. contorta which also has been affected by adult tree mortality caused by windthrows. The unplanted area has been kept a meadow and at the time of sampling, the field layer was dominated by Timothy grass (Phleum pratense), Wavy hair-grass (Deschampsia flexuosa), Couch grass (Elymus repens) and Wood crane's-bill (Geranium sylvaticum). No clear understory vegetation was found in the plots planted with L. sibirica, P. abies, P. contorta and P. sylvestris but the field layer was characterized by sporadic tufts of grass (Dechampsia cespitosa) and puzzlegrass (Equisetum sylvaticum). The bottom layer of the plots planted with Silver birch was dominated by Couch grass (Elymus repens) and Wood anemone (Anemone nemorosa). Further details of the site can be found in the paper by Alriksson and Eriksson (1998).

Soil organic matter sampling and processing

SOM samples were collected in mid-October 2015 from the incipient uppermost $F$ soil layer (i.e. the uppermost $3 \mathrm{~cm}$, each sample covering $25 \times 25 \mathrm{~cm}$ area). The $\mathrm{F}$ layer has been reported to show the greatest differences among tree species with respect to microbial activity (Kanerva and Smolander 2007). No podzolization was evident in the profiles of the conifer plots but there was a clear distinction between the F layer and underlying A horizon with the mineral material. Although we assumed a similar sampling scheme for the $B$. pendula and meadow plots, the differences in humus formation among treatments resulted in samples also including the transition or top of the A horizon. In each plot, SOM samples were randomly collected from six points within three meters of the plot's center and combined into a bulk sample, resulting in a total of 18 bulk samples (three for each of the five tree species and one unplanted area). When sampling, relatively fresh organic residues, identifiable plant material, such as leaves or needles, wood or twigs were removed and areas close to the plot boundaries were avoided so that the samples were representative of the tree species planted in each plot. The thickness of the litter layer varied for the different species and more needles were present in the L. sibirica as compared to the other plots. The samples were stored at $4{ }^{\circ} \mathrm{C}$ for a week before further processing. In the laboratory, the soil was passed through a sieve $(5 \mathrm{~mm}$ mesh size) to homogenize the bulk samples and remove any traces of green tissue, roots, and other plant matter. All the samples were then frozen and stored at $-18{ }^{\circ} \mathrm{C}$.

Soil subsamples for incubation experiment were removed from the freezer after 3 weeks and thawed at $4{ }^{\circ} \mathrm{C}$ overnight. This sample handling and storage time does not significantly affect microbial activity after thawing (Stenberg et al. 1998; Tilston et al. 2010). The water and organic matter contents of thawed samples were 
determined by measuring changes in the weight of subsamples after drying at $105{ }^{\circ} \mathrm{C}$ for $24 \mathrm{~h}$ and the loss on ignition (LOI; $550{ }^{\circ} \mathrm{C}$ for $6 \mathrm{~h}$ ), respectively. Total C and $\mathrm{N}$ contents were determined using a Flash EA 2000 elemental analyzer (Thermo Fisher Scientific, Bremen, Germany) (Werner et al. 1999).

\section{Pyrolysis-GC-MS analysis}

SOM subsamples were taken from each bulk sample, freeze dried and tube-milled for $60 \mathrm{~s}$ (IKA®, Staufen, Germany). Next, triplicates of $200 \mu \mathrm{g}( \pm 10 \mu \mathrm{g}$; giving a total of 54 subsamples) were weighed (XP6, MettlerToledo, Zaventem, Belgium), and transferred to autosampler containers (Eco-cup SF, Frontier Laboratories, Japan). Initial Py-GC-MS conditions were taken from Gerber et al. (2012). Briefly, the analytical setup consisted of an oven pyrolyzer equipped with an autosampler (PY-2020iD and AS-1020E, FrontierLabs, Japan) connected to a GC/MS system (Agilent, 7890A5975C, Agilent Technologies AB, Sweden). The injector was operated with a split ratio of $16: 1$, using helium as the carrier gas. After $20 \mathrm{~s}$ of pyrolysis at $450{ }^{\circ} \mathrm{C}$, the pyrolysate was separated on a $\mathrm{J} \& \mathrm{~W}$ DB-5MS capillary column ( $30 \mathrm{~m}$ length, $0.25 \mathrm{~mm}$ diameter, $0.25 \mu \mathrm{m}$ film thickness; Agilent Technologies AB, Sweden). The oven temperature was initially set to $40{ }^{\circ} \mathrm{C}$ and was then increased at $32^{\circ} \mathrm{C} \mathrm{min}^{-1}$ to $100^{\circ} \mathrm{C}$, then at $6^{\circ} \mathrm{C} \mathrm{min}^{-1}$ to $120^{\circ} \mathrm{C}$, then at $15^{\circ} \mathrm{C} \min ^{-1}$ to $250{ }^{\circ} \mathrm{C}$, and finally at $32{ }^{\circ} \mathrm{C} \min ^{-1}$ to $320^{\circ} \mathrm{C}$. The total run time was $19 \mathrm{~min}$, and scanned mass spectra were recorded over the range $35-250 \mathrm{~m} / \mathrm{z}$. Peak detection was performed using the software supplied with the instrument (Chemstation; Agilent Technologies AB, Sweden). A pyrolysis temperature of $450{ }^{\circ} \mathrm{C}$ was used to avoid complete degradation of some specific organic matter biomarkers (Tolu et al. 2015 and references therein).

Data processing and analysis

Raw data files were converted to NetCDF format and exported using the software supplied with the instrument (Agilent Chemstation Data Analysis Version E.02.00.493) and processed with 'R' (version 2.15.2, 64 bits) using the GC/MS data processing methodology described by Jonsson et al. (2005). This processing pipeline produces a text file containing mass spectroscopic data for each peak and a data table listing the peak areas for each sample after chromatogram smoothing and alignment, background correction, and multivariate curve resolution by alternate regression (MCR-AR) (Karjalainen 1989). Tables of peak areas for each sample were imported into the mass spectra library searching tool 'NIST MS Search 2.0' (http://chemdata.nist.gov/dokuwiki/doku.php?id= chemdata:ms-search) to identify peaks based on spectra from the 'NIST/EPA/NIH 2011' library and the list of compounds published by (Tolu et al. 2015).

To avoid loss of peak resolution and separation during data processing, we processed chromatograms of samples with low and high signal separately, in addition to processing all chromatograms together. Processing the chromatograms of all samples resulted in the identification of 71 compounds which is $62 \%$ of total detected peaks (or $86 \% \pm 1 \%$ SD of total extracted peak area) this included $\mathrm{CO}_{2}$ and acetic acid. Processing the chromatograms of samples with high signal resulted in the identification of 27 additional compounds while processing chromatograms with low signal resulted in the identification of 15 additional compounds, which makes in total 113 compounds, $\mathrm{CO}_{2}$ and acetic acid included. The occurrence of $\mathrm{CO}_{2}$ and acetic acid have been proven to be pyrolysis byproducts (Tolu et al. 2015) and were removed prior to normalizing the peak areas of the compounds identified in each sample such that they summed to $100 \%$. The set of 111 pyrolytic organic compounds that were included in the analysis closely resembles the sets of compounds identified in other PyGC-MS studies on soil, peat, and sediment samples (e.g. Peulvé et al. 1996; Buurman et al. 2005; Schellekens et al. 2009; Micić et al. 2011) (Table S1, Supporting information).

$\mathrm{CO}_{2}$ production rates and kinetic parameters

To optimize moisture conditions for microbial activity, the water content of the thawed SOM samples was adjusted to a water potential of $-25 \mathrm{kPa}$ before incubations (Ilstedt et al. 2000). Twenty grams of wet soil (equivalent to $13 \pm 0.6 ; 12 \pm 2.4 ; 8.9 \pm 0.4 ; 11.2 \pm 1.9$; $9.6 \pm 1.1$ and $9.3 \pm 1.7 \mathrm{~g}$ dry weight for control, B. pendula, L. sibirica, P. abies, P. contorta and P. sylvestris soil samples respectively) were placed in $250 \mathrm{ml}$ airtight incubation jars (Nalgene, Thermo Fisher Scientific). One SOM sample from each bulk sample $(n=18)$ was incubated at each of four temperatures (4, 9,14 , and $19^{\circ} \mathrm{C}$ ), resulting in a total of 72 incubations. The biogenic $\mathrm{CO}_{2}$ production during each incubation 
was measured hourly using a respirometer (Chapman 1971; Respicond VI, Nordgren Innovations, Djäkneboda, Sweden; Nordgren 1988). The incubation jars were installed in the apparatus, each of which was equipped with a small vessel containing $10 \mathrm{ml} \mathrm{KOH}$ $(0.5 \mathrm{M})$ and two platinum electrodes. The jars were placed in an insulated water bath whose temperature was tightly controlled $\left( \pm 0.02{ }^{\circ} \mathrm{C}\right) . \mathrm{CO}_{2}$ produced by SOM respiration was trapped in the $\mathrm{KOH}$ solution, causing its electrical conductivity to decrease; this decrease was measured by the platinum electrodes. The measured rate of conductivity change was then recalculated and expressed in $\mathrm{mg} \mathrm{CO}_{2} \mathrm{~g}^{-1} \mathrm{OM}$ dry weight (dw) $\mathrm{h}^{-1}$.

The following parameters were extracted from the respiration curves: Basal respiration (BR) was calculated as the average of 100 consecutive hours of $\mathrm{CO}_{2}$ measurements starting 3-4 days after the start of the incubation, when the samples' respiration rates had stabilized. The BR rates reflect the inherent metabolic properties of the microorganisms in the incubated sample. After the BR had been determined, the soil samples were treated with a substrate consisting of carbon (in the form of glucose) together with solutions of $\left(\mathrm{NH}_{4}\right)_{2} \mathrm{SO}_{4}$ and $\mathrm{KH}_{2} \mathrm{PO}_{4}$. The amount of added glucose amounted to $50 \mathrm{mg} \mathrm{C} \mathrm{g}^{-1} \mathrm{SOM}$, and the final $\mathrm{C}: \mathrm{N}: \mathrm{P}$ molar ratio for the added substrate was 181:13:1. Substrate-induced respiration (SIR) is defined as the immediate response in $\mathrm{CO}_{2}$ production upon addition of a $\mathrm{C}$ substrate at the level of substrate saturation. It is therefore a measure of the soil's microbial potential, i.e. the microbial biomass within the soil that is capable of degrading the added carbon substrate (Anderson and Domsch 1978). The SIR was calculated as the average of 5 hourly measurements following substrate addition. The ratio of the BR to the $\operatorname{SIR}\left(Q_{R}=B R / S I R\right)$ is the respiratory ratio, and is a measure of the actual activity of the $\mathrm{CO}_{2}$ producing community in the soil relative to the soil's potentially active microbial population (Blagodatskaya and Kuzyakov 2013).

\section{Determination of $\mathrm{Q}_{10}$}

To determine the temperature sensitivity of SOM decomposition, $\mathrm{Q}_{10}$ values were derived from the BRs measured at the four temperatures. $\mathrm{Q}_{10}$ is the factor by which rates of respiration change in response to a ten degree change in temperature. The respiration rate and its temperature dependency were described using an exponential model of the type suggested by Fang et al. (2005) (Eq. 1):

$Q_{10}=e^{\beta \times 10}$

Where $e$, is the base of the natural logarithm, $\beta$ is the exponent of exponential function that best fits the corresponding respiration and temperature data (calculated with eq. 2) and 10 is a factor corresponding to the 10degree difference in temperature. A curve-fitting model was used to calculate the standard deviation of the exponent $\beta$. The standard error (SE) for $\mathrm{Q}_{10}$ was obtained from the slope of the Taylor expansion according to eq. 2 :

$S E\left(Q_{10}\right)=10 \times Q_{10} \times S E(\beta)$

\section{Statistical analysis}

The distributional properties of the data met the assumptions of normal distribution. One-way ANOVA followed by a Tukey's multiple comparisons test $(p<0.05)$ was used to evaluate the significance of differences in soil characteristics (e.g. $\mathrm{C}$ and $\mathrm{N}$ content, $\mathrm{pH}, \mathrm{OM}$ content) between all treatments, including the control treatment (i.e. the abandoned meadow plot). To analyze main and interaction effects of tree species and temperature on the BR, a two-way ANOVA was performed with temperature and tree species as factors, followed by a Tukey's multiple comparison test. Two-way ANOVA was also used to explore main and interaction effects of tree species and incubation temperature on the ratio of actual to potential respiration $\left(\mathrm{Q}_{\mathrm{R}}\right)$. The ANOVA was followed by a Tukey's multiple comparisons post hoc test $(p<0.05)$.

To evaluate the effects of tree species on the molecular composition of the SOM, a principal component analysis (PCA) was performed on scaled and centered data on the 111 identified pyrolytic organic fragments and the other SOM descriptors (i.e. $\mathrm{pH}, \mathrm{C}: \mathrm{N}$ ratio, SOM content, $\mathrm{C}$ and $\mathrm{N} \%$ ). Because we specifically wanted to explore the effects of the planted tree species on the organic chemistry of the SOM, the abandoned meadow plots were not included in this analysis. The PCA model generated three significant components. Although PC2 and PC3 both explained $11 \%$ of the total variance, the inclusion of PC2 in the model systematically reduced the model's 
performance, which is indicative of a factor associated exclusively with noise. Therefore, only PC1 and PC3 were considered in subsequent analyses as explanatory of the data variance.

To test the hypothesis that SOM content, BR, SIR, $\mathrm{Q}_{10}$, and $\mathrm{Q}_{\mathrm{R}}$ can be explained by the organo-chemical composition of the SOM, we performed a partial least squares (PLS) analysis. PLS separates the systematic variation in the SOM's molecular composition $(\mathrm{X})$ into principal components linearly related to $\mathrm{Y}$ (SOM content, $\mathrm{BR}, \mathrm{SIR}, \mathrm{Q}_{10}$, and $\mathrm{Q}_{\mathrm{R}}$ ). The $\mathrm{R}^{2}$ value obtained in this analysis represents the variance explained by the best fit model, while $\mathrm{Q}^{2}$ represents the proportion of the variance explained by the $\mathrm{x}$-validation prediction. Model components were added only if they increased both $\mathrm{R}^{2}$ and $\mathrm{Q}^{2}$. Variable of importance (VIP) values at a significance level of $95 \%$ were used to identify important and significant variables for the PLS analysis. X variables with VIP values $>1$ and significant coefficients were included in the model because they can be considered to be the most influential variables (Eriksson et al. 2001). The PCA and PLS analyses were performed using the SIMCA-P software package version 14.0 (Umetrics, Umeå, Sweden).

\section{Results}

Soil characteristics

Fifty years of tree growth had significantly increased the soil C:N ratio in the planted plots relative to that in the control plots (Fig. 1a). The C:N ratio for the control plots $(15.1 \pm 0.5)$ was significantly lower than those for soils formed under L. sibirica, P. contorta and $P$. sylvestris and $P$. abies, but did not differ significantly from that for soils formed under B. pendula, $(20 \pm 2)$ (ANOVA, $\mathrm{r}^{2}=0.68, p=0.009$ ). No significant differences in $\mathrm{C}: \mathrm{N}$ ratios were detected among tree treatments (Fig. 1a). The $\mathrm{C}$ and $\mathrm{N}$ content of the soil samples were not significantly different in the planted plots compared to the control (ANOVA, $\mathrm{r}^{2}=0.40, p=0.2$ and $\mathrm{r}^{2}=0.27$, $p=0.5$ for $\mathrm{C}$ and $\mathrm{N} \%$, respectively), but there was a general trend towards higher $\mathrm{C}$ and $\mathrm{N}$ content in the conifer tree treatment plots - particularly the $P$. abies plots (Fig. 1b and c).

In addition, no significant differences in SOM content were detected (ANOVA, $\mathrm{r}^{2}=0.44, p=$ 0.18 ), among plots, but there was a general trend towards higher $\mathrm{OM}$ content in the tree treatment
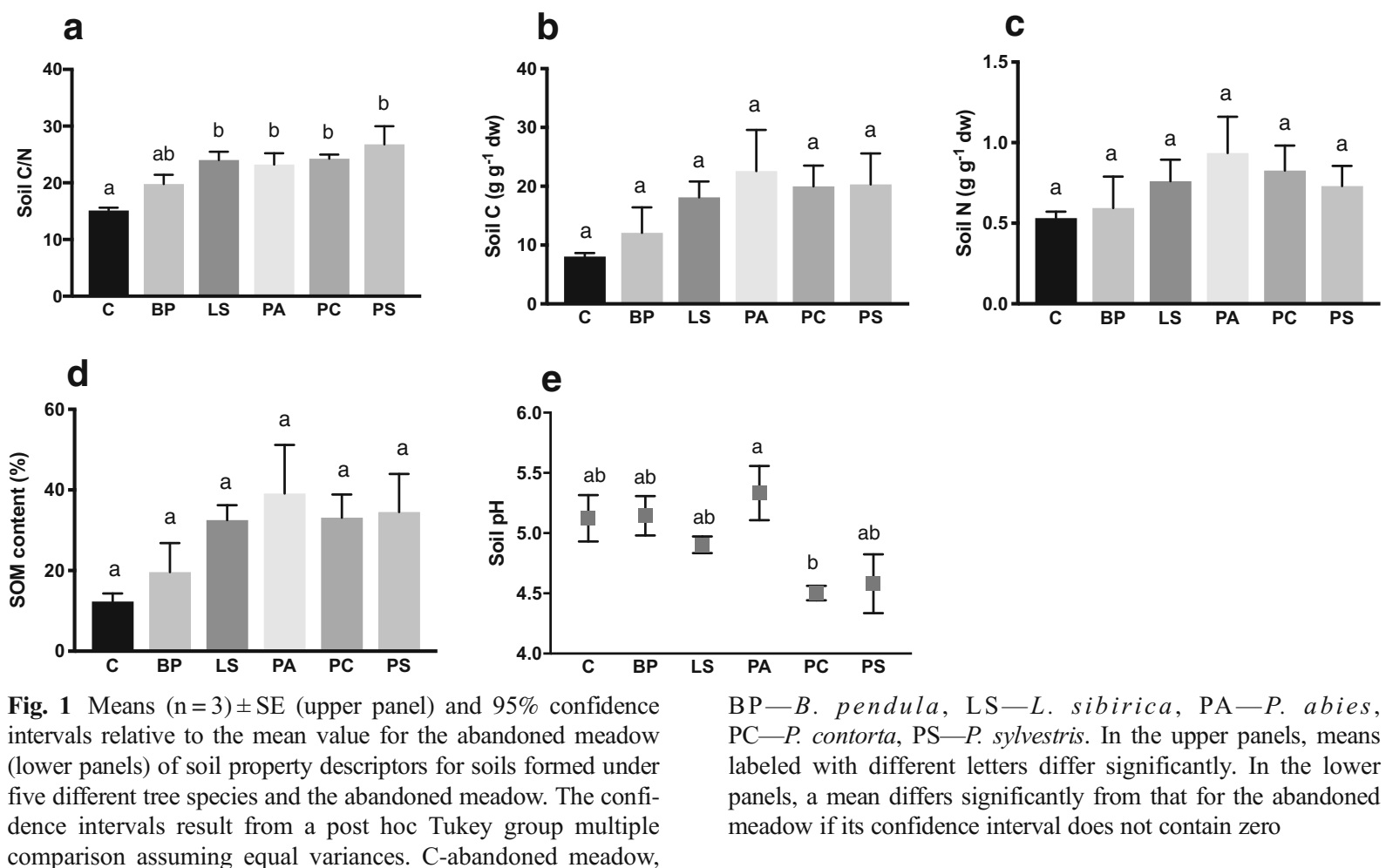

Fig. 1 Means $(n=3) \pm S E$ (upper panel) and 95\% confidence intervals relative to the mean value for the abandoned meadow (lower panels) of soil property descriptors for soils formed under five different tree species and the abandoned meadow. The confidence intervals result from a post hoc Tukey group multiple comparison assuming equal variances. C-abandoned meadow, 
plots - particularly the $P$. abies and $P$. sylvestris plots ( $39 \pm 12$ and $34.5 \pm 9.5 \%$ OM respectively) compared to the control plots $(12.3 \pm 2 \% \mathrm{OM})$ (Fig. 1d). There were also no significant differences in soil $\mathrm{pH}$ between the abandoned meadow plots and plots with trees, although the $\mathrm{pH}$ values of $P$. sylvestris and $P$. contorta plots were somewhat lower than the others. There was a significant difference in $\mathrm{pH}$ between $L$. contorta and $P$. abies plots $(p=0.04)$ (Fig. 1e).

\section{Organo-chemical composition of the SOM}

The two significant PCA components based on the 111 identified pyrolytic fragments and found to significantly contribute to the model (see methods) explained $64 \%$ of the variation in the organic chemical composition of the forest soil samples $\left(\mathrm{R}^{2}=\right.$ $0.64, \mathrm{Q}^{2}=0.6, n=15$ Fig. 2 a and $\mathrm{b}$, Table $\mathrm{S} 1$, Supporting information). Data on the relative contributions of the pyrolytic fragments are summarized in Table S2. The first principal component (Fig. 2, $\mathrm{PC} 1 ; 53 \%$ of total variance) explained variance in the relative abundance of different pyrolytic fragments originating from differences in tree species. Pyrolytic fragments derived from SOM developed under $B$. pendula (PC1, positive loadings) differed from those derived from SOM developed under coniferous tree species, including the deciduous conifer L. sibirica (PC1, negative loadings). In particular, pyrolytic fragments of carbohydrate polymers (e.g. D-glucopyranose and levoglucosan) associated with lignin (guaiacol) subunits were associated with samples from the conifers. The pyrolytic fragments from $B$. pendula were rich in aliphatic carbons such as short and intermediate-chain n-alkanes (C18-23), alkan-2-ones (C27-30), and n-alkenes (C22-26), as well as microbially originated $\mathrm{N}$-containing compounds (specifically, pyrrole and pyridine) together with lignin subunits (syringols), and low molecular weight carbohydrates (e.g. 2-furaldehyde and $\alpha$ acetobutyrolactone).

The second significant PCA component explaining $11 \%$ of the total variation separated pyrolytic fragments indicative of within-species variation amongst the treatment blocks in the study (Fig. 2). Specifically, carbohydrate pyrolysis products (e.g. hydroxyl-2-propanone), phenols (e.g. catechol), and indole were associated with
P. sylvestris and $P$. abies plots in block 3, and were negatively correlated with pyrolytic fragments of carbohydrate polymers (e.g. levoglucosan) and steroids (e.g. stigmastan-3,5-diene) associated with the P. sylvestris and P. abies plots in blocks 1 and 2, which contribute strongly to the second PC but not to the first PC (Fig. 2). Thus, the experimental blocks' spatial heterogeneity contributed modestly to the observed variation in the organo-chemical composition of the SOM, explaining $11 \%$ of the total variance.

Respiration rates from soil organic matter and $\mathrm{Q}_{10}$ responses for basal respiration

The temperature sensitivity of BR (as estimated by the $\mathrm{Q}_{10}$ variable) at temperatures between 4 and $19{ }^{\circ} \mathrm{C}$ was not significantly different between any of the treatments (Fig. 3). However, a two-way ANOVA of basal respiration responses using tree species and incubation temperature as factors revealed that while temperature alone accounts for $76 \%$ of the explained variation $(p<0.001)$, tree species contribute $11 \%(\mathrm{p}<0.001)$, and the tree species-temperature interaction also contributes significantly, accounting for $5 \%$ of the explained variation $\left(p=0.017, \mathrm{r}^{2}=0.93\right.$, full model with interaction effects). The BR rates were mainly affected by tree species at 14 and $19{ }^{\circ} \mathrm{C}$ but not at 4 and $9{ }^{\circ} \mathrm{C}$ (Fig. 4). The basal rates of microbial respiration in soil developed under $P$. sylvestris plots were significantly higher than those for soils developed under other treatments at both $14{ }^{\circ} \mathrm{C}$ and $19{ }^{\circ} \mathrm{C}$ (Fig. 4).

Substrate-Induced Respiration (SIR) after glucose addition represents the maximum potential respiration by the microorganisms in the sample. A twoway ANOVA of the mean ratios of basal respiration to substrate-induced respiration $\left(\mathrm{Q}_{\mathrm{R}}\right)$ (Table 1), using tree species and incubation temperature as factors revealed that tree species accounted for $44 \%$ of the observed variation $(p<0.001)$. Temperature and its interaction with tree species were not significant ( $p=0.79$ and $p=0.64$ respectively). Data on SIR are presented in the Supporting information (see fig. S1). In general, $Q_{R}$ was significantly lower for soils from the abandoned meadow and B. pendula plots than for conifer tree treatments at $14{ }^{\circ} \mathrm{C}$. The $\mathrm{Q}_{\mathrm{R}}$ values for the tree treatments were 

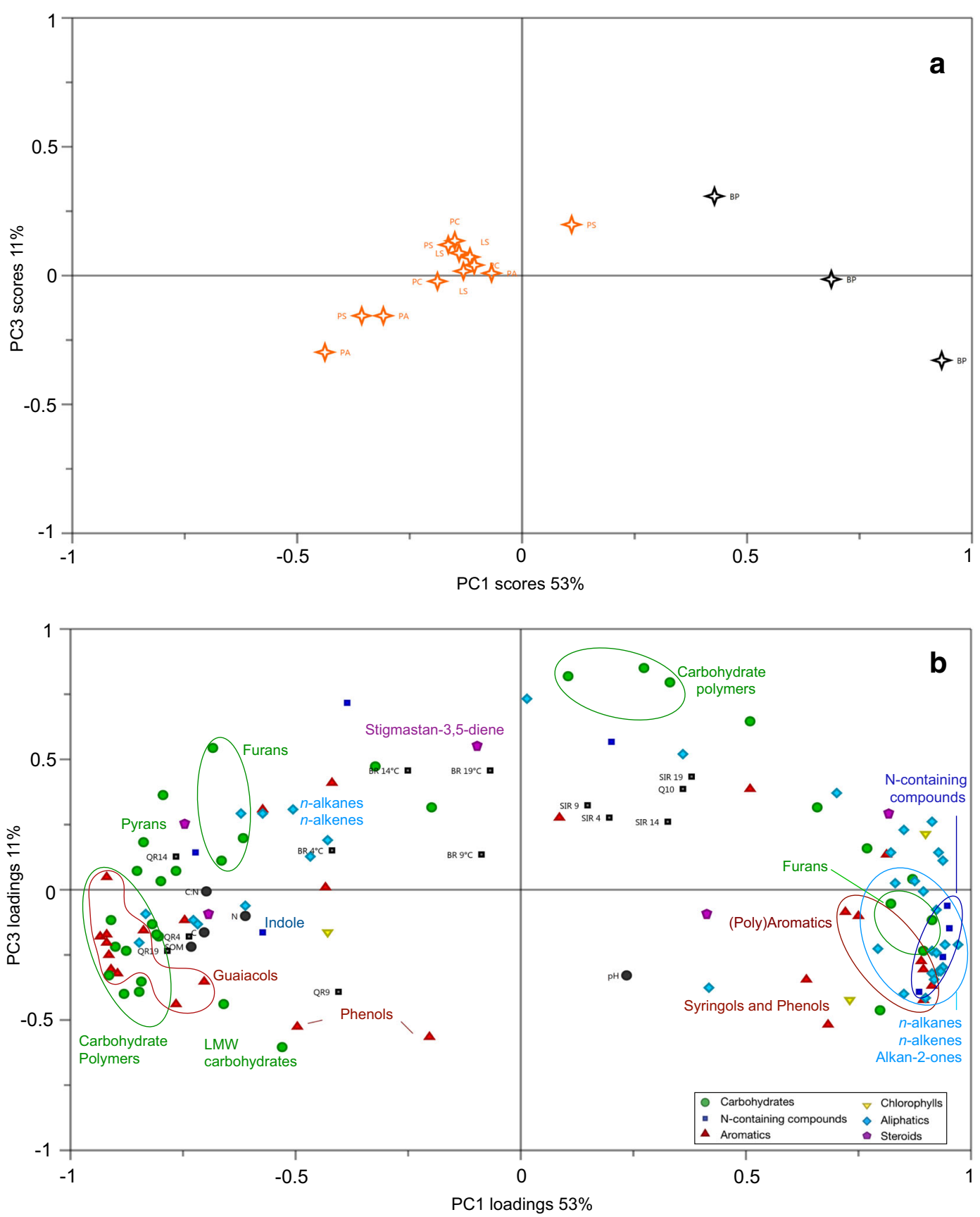

Fig. 2 Score (a) and loading (b) plots for PC1 and PC3 of the PCA based on the organo-chemical composition of the SOM, SOM descriptors ( $\mathrm{pH}, \mathrm{C}: \mathrm{N}$ ratio, SOM content, OM_C, and OM_N; black circles), respiratory ratio $\left(Q_{R}\right)$, basal respiration $(\mathrm{BR})^{-}$, and $\mathrm{Q}_{10}$ (grey squares). PC scores of the treed plots are

not significantly different from that for the control plots at $4{ }^{\circ} \mathrm{C}(p>0.05)$, and only the $P$. contorta and $P$. abies plots exhibited significantly higher $\mathrm{Q}_{\mathrm{R}}$ values than the abandoned meadow at 9 and $19{ }^{\circ} \mathrm{C}$ indicated by orange stars (LS-L. sibirica, PA-P. abies, $\mathrm{PC}-P$. contorta, $\mathrm{PS}-P$. sylvestris) and black stars $\left(\mathrm{BP}-B\right.$. pendula). Total explained variance $\mathrm{R}^{2}=0.64 \mathrm{Q}^{2}=0.6$, $\mathrm{n}=15,(\mathrm{PC} 153 \%, \mathrm{PC} 211 \%)$

( $p=0.01$ and $p=0.004$, respectively). Among tree species treatments $B$. pendula plots showed significantly different $\mathrm{Q}_{\mathrm{R}}$ values compared to $P$. abies at $4{ }^{\circ} \mathrm{C}(p=0.05)$. 


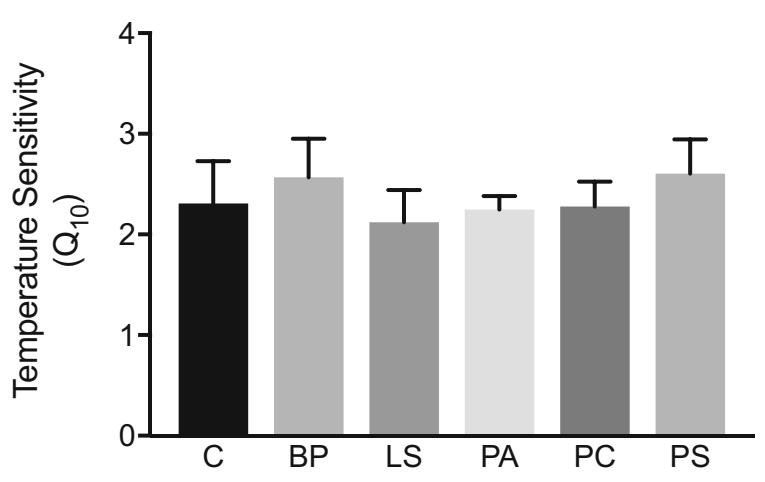

Fig. 3 The average $(n=3 \pm S E)$ temperature response $\left(Q_{10}\right)$ of the basal respiration (BR) for soil incubations from each tree plantation treatment and the abandoned meadow plots. Tree species had no significant effect on the $\mathrm{Q}_{10}$ temperature sensitivity of basal respiration. C- abandoned meadow, $\mathrm{BP}-B$. pendula, LS - L. sibirica, PA-P. abies, PC - P. contorta, PS - P. sylvestris

Relationship between respiration, temperature sensitivity and SOM organic chemical composition

The PCA analysis included not only SOM pyrolytic fragments but also conventional SOM descriptors $(\mathrm{pH}$, $\mathrm{C}: \mathrm{N}$ ratio, $\mathrm{SOM}$ content, $\mathrm{C}$ and $\mathrm{N} \%$ ) and the respiratory responses $\mathrm{BR}, \mathrm{SIR}$ and $\mathrm{Q}_{\mathrm{R}}\left(\mathrm{R}^{2}=0.63, \mathrm{Q}^{2}=0.5, n=15\right.$; Fig. $2 \mathrm{a}$ and $\mathrm{b})$. PC1 revealed that SOM from coniferous tree treatments was clearly associated to a high $\mathrm{C}: \mathrm{N}$ ratio, high $\mathrm{BR}$ at $4{ }^{\circ} \mathrm{C}$, and high respiratory ratios $\left(\mathrm{Q}_{\mathrm{R}}\right)$ at 4,14 , and $19{ }^{\circ} \mathrm{C}$. These variables also correlated positively with most of the carbohydrate polymers and oligomers and lignin (guaiacol) subunits, stigmastan-4en-3-one, $\alpha$-Tocopherol, pyrans (4-Hydroxy-5,6dihydro-(2H)-pyran-2-one), and furans ((2H)-furan-3one), as indicated by their negative PC1 loadings.

SOM from $B$. pendula plots had high PC1 loadings, and was thus characterized by high relative proportions of lignin (syringol) subunits, furans (e.g. $\alpha-$ acetobutyrolactone), N-containing compounds and short and intermediate-chain n-alkanes (C18-23), alkan-2-ones (C27-30), and n-alkenes (C22-26). 35\% of $\mathrm{N}$ - containing compounds in B. pendula plots is comprise by pyrolytic fragments related to pyrrole and pyridine (see Table S1 supplementary). The PCA also revealed that $\mathrm{pH}, \mathrm{Q}_{10}$, basal respiration rates at 9, 14 and $19{ }^{\circ} \mathrm{C}$ and SIR at the same temperatures were not correlated to any of the other variables, i.e. they all had low PC1 loadings.

A Partial Least Squares (PLS) regression analysis was performed to characterize the dependence of the soil chemical and soil biological variables on the relative abundance of different pyrolysis

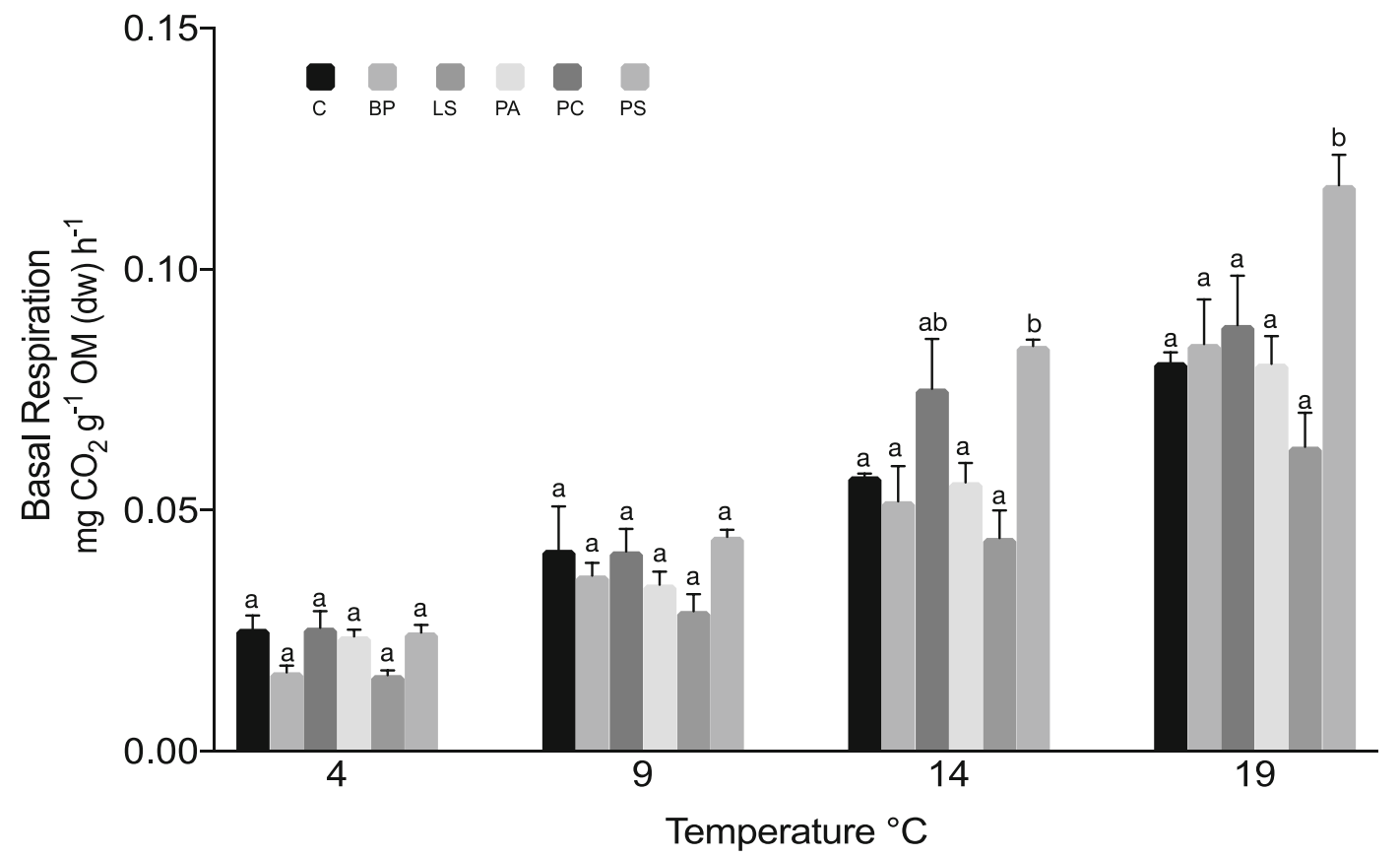

Fig. 4 Mean $(n=3 \pm S E)$ basal respiration rates $\left(\mathrm{mg} \mathrm{CO}_{2} \mathrm{~g}^{-1} \mathrm{OM}\right.$ $(\mathrm{dw}) \mathrm{h}^{-1}$ ) for soils from the abandoned meadow and tree treatment plots at $4,9,14$, and $19^{\circ} \mathrm{C}$. Different letters above the bars denote significant differences $(\mathrm{p}<0.05)$ in respiration rates at the indicated temperature. C- abandoned meadow, $\mathrm{BP}-B$. pendula, LS - L. sibirica, PA-P. abies, PC-P. contorta, PS - P. sylvestris 
Table 1 Mean respiratory ratios $\left(\mathrm{Q}_{\mathrm{R}}\right)(n=3 \pm \mathrm{SE})$ for soil samples incubated at $4,9,14$ and $19^{\circ} \mathrm{C}$, expressed as the ratio of the respiration rates before (basal respiration; BR) and after the addition of glucose at substrate saturation level (substrate-induced respiration; SIR)

\begin{tabular}{|c|c|c|c|c|c|c|c|c|}
\hline & Mean $4{ }^{\circ} \mathrm{C}$ & SE & Mean $9{ }^{\circ} \mathrm{C}$ & SE & Mean $14^{\circ} \mathrm{C}$ & $\mathrm{SE}$ & Mean $19^{\circ} \mathrm{C}$ & SE \\
\hline P. abies & $0.34^{b}$ & 0.07 & 0.28 & 0.05 & $0.30^{b}$ & 0.06 & $0.33^{b}$ & 0.03 \\
\hline P. contorta & 0.25 & 0.02 & $0.31^{\mathrm{b}}$ & 0.05 & $0.29^{b}$ & 0.03 & 0.27 & 0.04 \\
\hline P. sylvestris & 0.26 & 0.08 & 0.24 & 0.03 & $0.31^{b}$ & 0.03 & 0.27 & 0.03 \\
\hline L. sibirica & 0.31 & 0.04 & 0.27 & 0.02 & 0.27 & 0.02 & 0.27 & 0.01 \\
\hline B. pendula & $0.19^{a}$ & 0.05 & 0.24 & 0.04 & 0.19 & 0.06 & 0.19 & 0.02 \\
\hline Control & 0.24 & 0.06 & $0.15^{\mathbf{a}}$ & 0.04 & $0.13^{\mathrm{a}}$ & 0.02 & $0.15^{\mathrm{a}}$ & 0.03 \\
\hline
\end{tabular}

Different letters above the mean $\mathrm{Q}_{\mathrm{R}}$ values denote significant differences $(p<0.05)$ for abandoned meadow plots and tree treatments and between tree treatments at different temperatures

fragments (Fig. 5, Table 2). Only data for soil samples from tree covered plots were included in this analysis since the overall aim of the study was to investigate differences among tree species. The pyrolysis-derived fragments explained $68 \%$ of the variation in the properties of the SOM $\left(R^{2} Y=\right.$ $0.68, \mathrm{Q}^{2}=0.63, \mathrm{R}^{2} \mathrm{X}=0.76, n=15$; Fig. 5a). This model confirmed the PCA-based finding that the SOM content had a strong negative correlation with pyrolytic fragments of short and mid-length chain n-alkanes (C18-24) and N-containing compounds (e.g. pyrrole, pyridine, and the Pro-Pro diketopiperazine), which were associated with soils in the B. pendula treatment. The SOM content also had a strong positive correlation with pyrolytic fragments of levosugars and lignin (guaiacol) subunits, which were associated with the coniferous tree treatments (Fig. 5a). The variable of importance (VIP) plots (data not shown) indicated that the pyrolysis compounds with the highest importance in the model were conyferol and dihydroconyferyl alcohol, pyrolytic fragments of short-chain n-alkenes (C18-21), and three carbohydrate degradation products: 1,4:3,6-dianhydro- $\alpha$-dglucopyranose, 2-furaldehyde, and 2,3-dihydrobenzofuran (Fig. 5a).

Among the measures of $\mathrm{CO}_{2}$ production from the soil samples, the ratio of basal respiration to substrateinduced respiration $\left(B R: S I R=Q_{R}\right)$ stood out as being very significantly dependent on the composition of the pyrolysis fragments at all four incubation temperatures (Table 2). Between 68 and $81 \%$ of the total variance in $\mathrm{Q}_{\mathrm{R}}$ at the four temperatures was explained by highly significant PLS models (Table 2, Table S3, Fig. 5 b and c). Conversely, the individual respiratory components
(BR and SIR) were either not significantly explained or

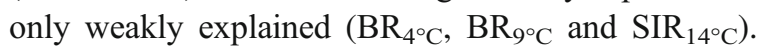
The only exception was $\operatorname{SIR}_{19}{ }^{\circ} \mathrm{C}$, for which $60 \%$ of the variance was explained (Table 2). The PLS models revealed that $\mathrm{Q}_{\mathrm{R}}$ values for all tested temperatures were largely positively correlated to the pyrolysis fragments' content of ligno-cellulose complexes, i.e. carbohydrate polymers and lignin (guaiacol) subunits (e.g. Figure $5 \mathrm{~b}$ and $\mathrm{c}$ show the model results for 19 and $4{ }^{\circ} \mathrm{C}$ ). In addition, the $\mathrm{Q}_{\mathrm{R}}$ values at all temperatures correlated strongly and negatively with the relative abundance of aliphatics, N-containing compounds, and low molecular weight carbohydrates. Variable of importance (VIP) plots (data not shown) showed that the importance of

Table 2 Model performance statistics for the PLS analysis of the organo-chemical composition of SOM (x variables). The response variables used were basal respiration $(\mathrm{BR})$, substrate induced respiration $(\mathrm{SIR})$ and respiratory quotient $\left(\mathrm{Q}_{\mathrm{R}}\right)$ at different temperatures

\begin{tabular}{lllll}
\hline PLS model & $R^{2} Y$ & $Q^{2}$ & $R^{2} X$ & Components \\
\hline BR $4{ }^{\circ} \mathrm{C}$ & 0.37 & 0.33 & 0.81 & 1 \\
BR $9{ }^{\circ} \mathrm{C}$ & 0.36 & 0.27 & 0.70 & 1 \\
BR $14{ }^{\circ} \mathrm{C}$ & n.s. & n.s. & n.s. & 0 \\
BR $19{ }^{\circ} \mathrm{C}$ & n.s. & n.s. & n.s. & 0 \\
SIR $4{ }^{\circ} \mathrm{C}$ & n.s. & n.s. & n.s. & 0 \\
SIR $9{ }^{\circ} \mathrm{C}$ & n.s. & n.s. & n.s. & 0 \\
SIR $14{ }^{\circ} \mathrm{C}$ & 0.32 & 0.18 & 0.62 & 1 \\
SIR $19{ }^{\circ} \mathrm{C}$ & 0.60 & 0.52 & 0.39 & 1 \\
QR $4{ }^{\circ} \mathrm{C}$ & 0.68 & 0.63 & 0.85 & 1 \\
QR $9{ }^{\circ} \mathrm{C}$ & 0.80 & 0.63 & 0.75 & 2 \\
QR $14{ }^{\circ} \mathrm{C}$ & 0.81 & 0.76 & 0.88 & 1 \\
QR $19{ }^{\circ} \mathrm{C}$ & 0.78 & 0.77 & 0.76 & 1 \\
\hline
\end{tabular}


pyrolytic compounds indicative of low molecular weight carbohydrates in the $\mathrm{Q}_{\mathrm{R}}$ models increased at lower temperatures (Fig. 5 b and c, Table S3).

The temperature sensitivity $\left(\mathrm{Q}_{10}\right)$ of saprotrophic respiration was not significantly explained by the pyrolysis data on SOM organo-chemical composition. Crossvalidation of the PLS analysis generated 2 components, but neither of them significantly explained the variance in the $\mathrm{Q}_{10}$ temperature sensitivity.

\section{Discussion}

Effects of tree species on organo-chemical composition of SOM

Detailed characterization of the soil organic matter (SOM) from the experimental plots revealed that different tree species influence SOM genesis significantly by changing the topsoil's SOM content and its organochemical composition. We show that after almost half a century of tree growth, a tree-type specific molecular fingerprint is evident in SOM formed under conifers and $B$. pendula trees. We also show that SOM developed under coniferous trees was richer in less-degraded lignocellulose complexes, i.e. high molecular mass carbohydrates strongly associated with lignin compounds rich in guiacyl (G) subunits (Hedges and Mann 1979; Kögel et al. 1988). This is consistent with the results shown by Hilli et al. (2012) using pyrolysis-GC-MS analyses on unfractionated samples from boreal soils. Hilli et al. (2012) however, used higher pyrolysis temperatures as compared to our study which might explain why they observed comparatively more lignin- or other polyphenol-derived substances in their samples. Previous reports also suggest the compounds we observe are indicative of relatively non-degraded SOM (Sollins et al. 1996; Helfrich et al. 2006; Vancampenhout et al. 2009).

Pyrolysis products of small polysaccharides and some microbial material (e.g. furans and furaldehydes) (Schellekens et al. 2009) as well as steroids were also associated with SOM from plots planted with conifers. Steroids have been found to comprise a large proportion of the compounds found in organic matter layers of boreal soils linked to plant root litter production (Stark et al. 2012). $\beta$-sitosterol, stigmasterol and campesterol are the major plant sterols, of which $\beta$-sitosterol is the most common in soils (Naafs et al. 2004; Kanerva et al. 2008). Steroids are used as indicators of SOM preservation and the biodegradation status of plant material because they are readily degraded in the environment (Mackenzie et al. 1982; Simpson and Simpson 2012). In our study, the relative abundance of $\beta$-sitosterol compared to that of three steroid biodegradation products (stigmastan-3,5-diene, stigmast-4-en-3-one, and stigmastan-3,5-dien-7-one) was higher in plots planted with coniferous species, suggesting that steroids from coniferous trees were better preserved relative to B. pendula and abandoned meadow plots (Table $\mathrm{S} 1$ ).

In contrast to the conifer plots, SOM from plots planted with $B$. pendula contained compounds associated with more extensively decomposed plant and microbial material. The SOM from plots planted with B. pendula had relatively high proportions of bio-macromolecule degradation products such as intermediate-length n-alkenes and n-alkanes (C22-26) and long-chain cell wall lipids (C27C30 alkan-2-ones). Previous pyrolysis studies showed that these compounds derive from the degradation of suberin and cuticular waxes into shorter chains (van Bergen et al. 1998; Hajje and Jaffé 2006; Buurman and Roscoe 2011). SOM from $B$. pendula plots also contained lignin compounds rich in syringyl (S) subunits, which are known to be characteristic of SOM originating from broadleaved tree species or grasses (Hedges and Mann 1979; SaizJimenez and De Leeuw 1986; Kögel et al. 1988).

Notably, we found N-containing compounds (i.e. pyrrole and pyridine and Pro-Pro diketopiperazine) associated with SOM planted with B. pendula trees. These compounds are known to be specific pyrolysis products of proteins or amino acids (Fabbri et al. 2012) i.e. SOM precursors that could be of either plant or microbial origin (van Bergen et al. 1998; Schellekens et al. 2009). We found the N-containing compounds associated to low molecular weight carbohydrates and previous studies have shown this is a clear indicator of the presence of significant amounts of microbial SOM (Abelenda et al. 2011; Buurman and Roscoe 2011), high microbial activity and a high degree of decomposition (Schulten et al. 1992; Gleixner et al. 1999; Nierop et al. 2001; Chefetz et al. 2002; Schnitzer et al. 2006).

Overall, SOM formed in plots with coniferous species contained compounds indicative of comparatively low SOM degradation, with relatively high proportions of intact plant-derived molecules. On the other hand, SOM from $B$. pendula plots contained a higher proportion of products of microbial origin and plant biopolymer degradation products. Thus, in the B. pendula plots, microbial processes might be a key driver of the level of 


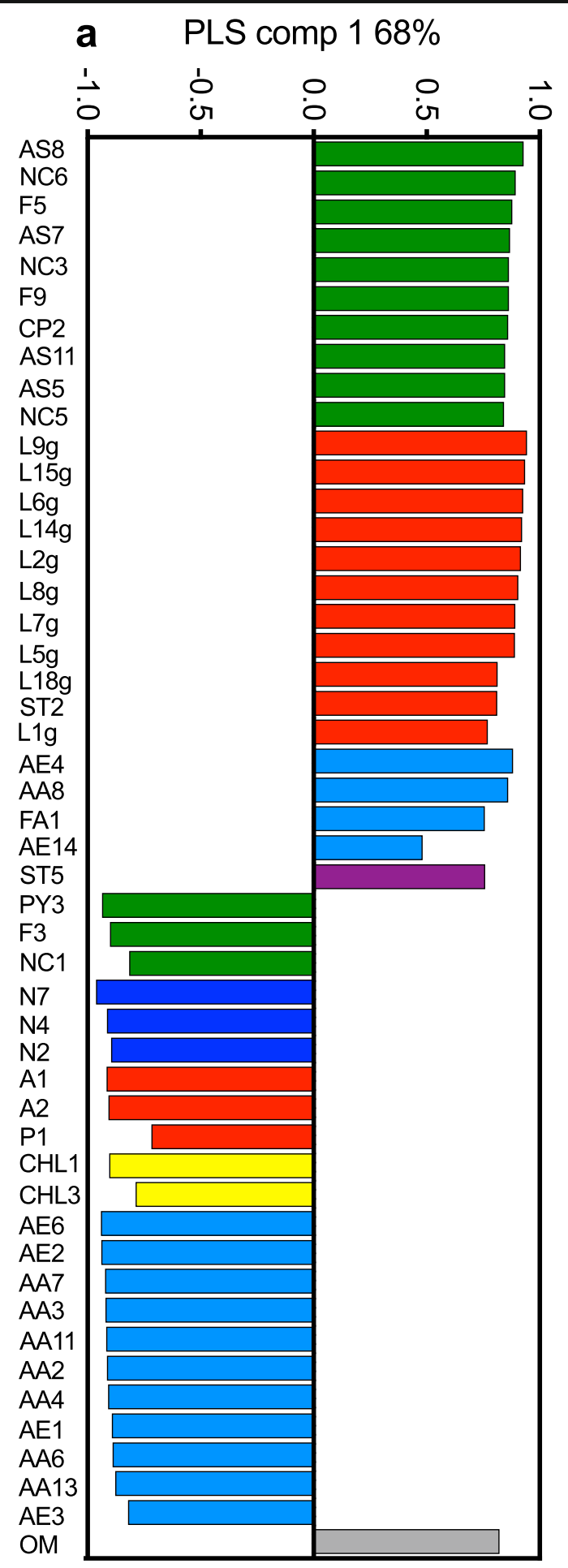

b PLS comp $178 \%$
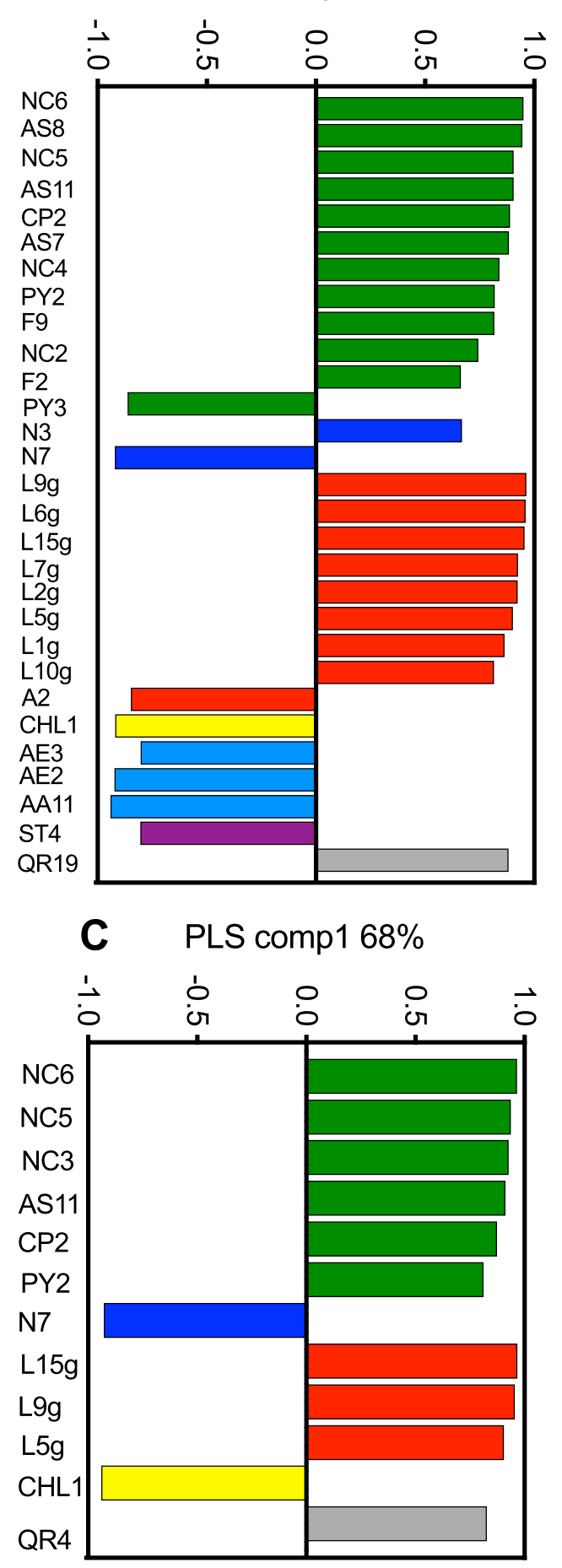
4 Fig. 5 Explained variance $\left(\mathrm{R}^{2}\right)$ of explanatory variables $(\mathrm{X})$ contributing to explained variance in the response variable $(\mathrm{Y})$ in the PLS models. The Y-variables were (a) organic matter content $(\mathrm{OM}),(\mathbf{b})$ respiratory ratio $\left(\mathrm{Q}_{\mathrm{R}}\right)$ at $19{ }^{\circ} \mathrm{C}$, and $(\mathbf{c}) \mathrm{Q}_{\mathrm{R}}$ at $4{ }^{\circ} \mathrm{C}$. The bars represent explained variance in either Y-variables (grey bars) or X-variables, i.e. pyrolysis fragments (green - carbohydrates; blue - N-containing compounds; red - aromatics; yellow - chlorophyll; light blue - aliphatics; purple - steroids). Only X variables significantly $(\mathrm{p}<0.05)$ contributing to the relevant PLS component are displayed. Positive $\mathrm{R}^{2}$ values indicate $\mathrm{X}$-variables positively correlated to $\mathrm{Y}$; negative $\mathrm{R}^{2}$ values indicate $\mathrm{X}$-variables negatively correlated to $\mathrm{Y}$. (See Table 2 for quantitative information on the explained variance in $\mathrm{Y}$ - and $\mathrm{X}$-variables). For descriptions of the X-variables, see Table S3

degradation we observe and also the long-term stabilization of SOM. Collectively, the variation in SOM composition reflects both the identity of the tree species planted half a century ago, differences in litter composition and the current state of SOM decomposition.

Only a handful of common garden studies have been reported on the effects of tree species on topsoils in the boreal region. Their results show that forest floor $\mathrm{C}$ and nutrient levels at sites planted with different tree species decrease in the order Picea $>$ Pinus $>$ broadleaf (Populus or Betula) (e.g. Vesterdal et al. 2013 and references therein). Similarly, the mean total SOM and N contents in our samples decreased in the order Picea $>$ Pinus $=$ Larix > Betula. Soil N, foliar concentrations of Ca, $\mathrm{N}$ or $\mathrm{C}: \mathrm{N}$ ratios and lignin: $\mathrm{N}$ ratios are commonly used as descriptors of SOM quality (Vesterdal et al. 2008, 2012). Previous studies in boreal soils have shown that soil C:N ratio can be positively linked to e.g. specific phenolic secondary metabolites and terpenes (Kanerva et al. 2008). We found that the SOM content, C, N \% and $\mathrm{C}: \mathrm{N}$ ratio were clearly related to tree species and the molecular composition of SOM.

The combination of general descriptors (e.g. C:N ratio and SOM content) and a detailed characterization of the SOM molecular composition explain a large part of the variation observed in our SOM samples and advances our understanding of the effects of individual tree species on SOM composition. Interestingly, a study (Alriksson and Eriksson 1998) conducted 20 years ago at the same experimental site as investigated herein reported no significant differences in the forest floor $\mathrm{C}$ or $\mathrm{N}$ content (estimated as $\mathrm{g} \mathrm{C} \mathrm{m}^{-2}$ ). We cannot observe a significant increase in $\mathrm{C}$ or $\mathrm{N}$ content after 44 years, although there is a strong trend towards increased $\mathrm{C}$ and
$\mathrm{N}$ content, especially in the $\mathrm{F}$ layer of coniferous plots. This confirms that changes induced in $\mathrm{C}$ and $\mathrm{N}$ content by different tree species are comparably slow. In comparison, changes in the molecular-level composition of the SOM is a much faster process.

Effect of tree species identity and SOM organic chemical composition on microbial respiration and its temperature sensitivity

The $\mathrm{Q}_{10}$ values were not significantly different among the tree species. However, the two-way ANOVA analysis of basal respiration at different temperatures showed a small but significant effect of tree species on basal respiration rates. In addition, the PCA analysis suggests a rather weak correlation between $\mathrm{Q}_{10}$ values and the organo-chemical composition of SOM. Nonetheless, it is evident that the effect of tree species on the temperature response was limited, in keeping with our earlier study on nearby boreal forest stands (Erhagen et al. 2013). Although Erhagen and coauthors (Erhagen et al. 2013) found $\mathrm{Q}_{10}$ to decrease as the carbonyl content of the SOM increased, it exhibited no correlation with any other class of organic compounds. The finding that the temperature sensitivity of soil $\mathrm{CO}_{2}$ production is apparently independent of the SOM organic chemical composition as determined by CP-MAS ${ }^{13} \mathrm{C}$ NMR (Erhagen et al. 2013) or Py-GC-MS (this work) is inconsistent with predictions based on the Arrhenius kinetic model (Bosatta and Ågren 1999; Davidson and Janssens 2006). The observation of clear differences in basal respiration rates of different tree species at 14 and $19{ }^{\circ} \mathrm{C}$, but not at 4 and $9{ }^{\circ} \mathrm{C}$ (Fig. 3) is intriguing. This indicates that some organic chemical compounds only decompose at higher incubation temperatures, presumably because the temperature affects substrate availability and thus the metabolic conditions of saprotrophs (Ågren and Wetterstedt 2007; Öquist et al. 2016).

According to the carbon-quality-temperature theory (CQT) theory (Bosatta and Ågren 1999), the decomposition of a complex substrate requires more enzymatic steps and a higher total activation energy than the decomposition of simple substrates and is therefore more sensitive to changes in the temperature. Empirical studies have both supported and contradicted this theory: some have reported the temperature sensitivity of complex substrates in SOM to be lower than that of simple substrates (Liski et al. 1999; Melillo et al. 2002) while 
others have reported them to be equal (Fang et al. 2005; Conen et al. 2006) or greater (Leifeld and Fuhrer 2005; Fierer et al. 2005; Erhagen et al. 2013). A meta-analysis of the available empirical evidence suggested that most of these studies actually agree with the CQT theory and thus support the hypothesis that temperature sensitivity increases with substrate complexity (Sierra 2012).

It is known that the availability of easily available $\mathrm{C}$ strongly limits saprotrophic metabolism in soils (e.g. Vance and Chapin 2001; Ekblad and Nordgren 2002). Changes in soil temperature and moisture may exacerbate this $\mathrm{C}$ limitation, further modifying the metabolic conditions of saprotrophs (Ågren and Wetterstedt 2007; Öquist et al. 2016). The pattern of microbial SOM utilization observed in this study mirrors that of microbial basal respiration and suggests that access to SOM changes with temperature, becoming more thermodynamically constrained at lower temperatures. One plausible explanation is that temperature drives changes in the physical and chemical environment that seemingly alter the accessibility of microbial enzymes to SOM aggregates, leading to changes in the rate of $\mathrm{C}$ mineralization.

Our $\mathrm{Q}_{\mathrm{R}}$ values ranged between 0.2 and 0.4 , which are somewhat high but still in the same range as previously reported values for forest soils (Wardle and Parkinson 1990; Blagodatskaya et al. 1996; Anan'eva et al. 2002). The $Q_{R}$ ratio has previously been used to evaluate the effects of various perturbations on soil ecosystems (Anderson and Domsch 1985; Insam and Domsch 1988) and the interactions between edaphic soil variables (e.g. soil temperature and moisture) and soil microbial communities and ecosystem processes (Wardle and Parkinson 1990; Wardle and Ghani 2018). One of the most striking findings of this study was that the ratio of the basal and substrate-induced respiration rates $\left(Q_{R}\right)$ was strongly dependent on the organic chemical composition of the SOM, even though the basal and substrate-induced respiration rates individually were largely independent of the organic chemical composition.

The dependence of $\mathrm{Q}_{\mathrm{R}}$ on the pyrolysis fragments data in our study indicate that the soil organic chemical composition is an important control of the relative fraction of the microbial community that are able to utilize the native SOM. Our data from the conifer treatments also indicate that the size of the active microbial community fraction relative to the potentially active community increases with the proportion of carbohydrates and phenolic compounds. Hilli et al. (2012) have shown that polyphenols and carbohydrate-derived compounds constitute major components of tree litter and organic soil layers in both the pine and spruce-dominated boreal sites in Finland. Several studies have also shown that phenolic compounds originating from deciduous and coniferous trees have the capacity to influence nutrient mineralization and enzymatic activities and constitute one major mechanisms by which tree species and associated organic matter quality affects carbon decomposition in boreal soils (Adamczyk et al. 2009, 2013, 2015).

A long-held conceptual model assumes that the decay of plant organic matter is a function of its organochemical structure (e.g. Melillo et al. 1982). However, Cotrufo et al. (2013) have suggested that the inverse might be true posing that the $\mathrm{C}$ chemistry controls litter decay through its effect on microbial substrate use efficiency. More recently it has been suggested that the organo-chemical composition of litter and SOM may be less important than ecosystem-level properties such as environmental and biological controls (Marín-Spiotta et al. 2014; Lehmann and Kleber 2015; Bradford et al. 2017; Maaroufi et al. 2017).

Both the work by Marin-Spiotta et al. (2014) and Lehmann and Kleber (2015) refers to long-term SOM stabilization (centuries to millennia), while biochemical composition has been shown to control decomposition of plant litter on the timescale of years (Schmidt et al. 2011 and references therein). The results presented here help us bridge the gap between the paradigms of short-term litter and long-term SOM decomposition showing that, on an intermediate timescale ( $\sim 50$ years), the molecular composition of the SOM is an important control on SOM mineralization in boreal forest soils. Our study was purposely limited to the incipient topsoil layers which are expected to be more rapidly affected by altered litter inputs (c.f. Augusto et al. 2015; Kohl et al. 2018). However, there is valid information in these observations as previous studies have suggested that the responses to climate of SOM pools of underlying mineral soils are often similar to topsoils (Kane et al. 2005; Pries et al. 2017). Our results are consistent with recent work on a boreal forest latitudinal gradient demonstrating that differences in vegetation, and thereby litter inputs, affect SOM chemistry more strongly compared to other differences associated with climate (Kohl et al. 2018).

We can conclude that over the course of almost half a century, tree species have a considerable impact on the molecular composition of SOM. A large fraction of the observed variation in the SOM content was explained by the SOM's organo-chemical composition. More 
importantly, the fraction of the microbial community able to utilize the native SOM was largely controlled by the SOM' organo-chemical composition. Although the temperature sensitivity of $\mathrm{CO}_{2}$ production $\left(\mathrm{Q}_{10}\right)$ could not be explained by the SOM composition, we observed that microbial access to SOM generated by conifers or $B$. pendula trees changes with the temperature, and that differences in thermodynamic constraints can affect the rates of decomposition. However, more research is needed to assess the effects of different tree species on SOM formation and how these effects change over time. Further studies should also examine and integrate the role of the abundance and composition of the soil microbial community in these processes to improve our understanding of the role of tree species on SOM dynamics in boreal soils.

Acknowledgments We acknowledge financial support from the Swedish National Research Council (contract 621-2011-4874 to MÖ and 2012-2855 to MN), the Swedish Research Council Formas (contract 214-2013- 834), The Kempe Foundation, (contract JCK1107), The Knut and Alice Wallenberg Foundation (2011.0228), the Carl Tryggers Foundation (contract 13:536). We thank Skogforsk for allowing sampling at the experimental site and the plant cell wall and carbohydrate analytical facility at Umeå Plant Science Centre (UPSC) hosted by Umeå Univ. and Swed. Univ. Agr. Sci. (SLU) and supported by Bio4Energy and TC4F for help with the Py-GC-MS analysis.

Data availability All data generated or analyzed during this study are included in this manuscript (and its supplementary information files).

\section{Compliance with ethical standards}

Conflict of interest The authors declare that they have no conflict of interest.

Open Access This article is distributed under the terms of the Creative Commons Attribution 4.0 International License (http:// creativecommons.org/licenses/by/4.0/), which permits unrestricted use, distribution, and reproduction in any medium, provided you give appropriate credit to the original author(s) and the source, provide a link to the Creative Commons license, and indicate if changes were made.

\section{References}

Abelenda MS, Buurman P, Camps Arbestain M, Kaal J, MartinezCortizas A, Gartzia-Bengoetxea N, Macías F (2011) Comparing $\mathrm{NaOH}$-extractable organic matter of acid forest soils that differ in their pedogenic trends: a pyrolysis-GC/MS study. Eur J Soil Sci 62:834-848
Adamczyk B, Kitunen V, Smolander A (2009) Soil Biology \& Biochemistry Polyphenol oxidase, tannase and proteolytic activity in relation to tannin concentration in the soil organic horizon under silver birch and Norway spruce. 41:20852093. https://doi.org/10.1016/j.soilbio.2009.07.018

Adamczyk S, Kiikkilä O, Kitunen V, Smolander A (2013) Potential response of soil processes to diterpenes, triterpenes and tannins : Nitrification, growth of microorganisms and precipitation of proteins. 67:47-52

Adamczyk S, Adamczyk B, Kitunen V, Smolander A (2015) Soil Biology \& Biochemistry Monoterpenes and higher terpenes may inhibit enzyme activities in boreal forest soil. 87:59-66

Ågren GI, Wetterstedt JAM (2007) What determines the temperature response of soil organic matter decomposition? Soil Biol Biochem 39:1794-1798. https://doi.org/10.1016/j. soilbio.2007.02.007

Alban DH (1982) Effects of nutrient accumulation by Aspen, spruce, and pine on soil properties 1. Soil Sci Soc Am J 46: $853-861$

Alexandersson H, Karlström C, Larsson-Mccann S (1991) Temperature and precipitation in Sweden 1961-1990. Reference normals. Swedish Meteorological and Hydrological Institute (SMHI). Meteorol Nr 81

Alriksson A, Eriksson HM (1998) Variations in mineral nutrient and $\mathrm{C}$ distribution in the soil and vegetation compartments of five temperate tree species in NE Sweden. For Ecol Manag 108:261-273. https://doi.org/10.1016/S0378-1127(98 )00230-8

Alriksson A, Eriksson HM (2001) Distribution of cd, cu, Pb and $\mathrm{Zn}$ in soil and vegetation compartments in stands of five boreal tree species in N.E. Sweden. Water, air. Soil Pollut Focus 1:461-475

Anan'eva ND, Blagodatskaya EV, Demkina TS (2002) Estimating the resistance of soil microbial complexes to natural and anthropogenic impacts. Eurasian Soil Sci 35:514-521

Anderson JPE, Domsch KH (1978) A physiological method for the quantitative measurement of microbial biomass in soils. Soil Biol Biochem 10:215-221. https://doi.org/10.1016 /0038-0717(78)90099-8

Anderson TH, Domsch KH (1985) Maintenance carbon requirements of actively-metabolizing microbial populations under in situ conditions. Soil Biol Biochem 17:197-203. https://doi.org/10.1016/0038-0717(85)90115-4

Arrhenius S (1889) Über die Reaktionsgeschwindigkeit bei der Inversion von Rohrzucker durch Säuren. Z Phys Chem 4: 226-248

Augusto L, De Schrijver A, Vesterdal L et al (2015) Influences of evergreen gymnosperm and deciduous angiosperm tree species on the functioning of temperate and boreal forests. Biol Rev 90:444-466. https://doi.org/10.1111/brv.12119

van Bergen PF, Nott CJ, Bull ID, Poulton PR, Evershed RP (1998) Organic geochemical studies of soils from the Rothamsted classical experiments - IV. Preliminary results from a study of the effect of soil $\mathrm{pH}$ on organic matter decay. Org Geochem 29:1779-1795

Binkley D (1995) The influence of tree species on forest soils: processes and patterns. In: proceeding of the trees and soil workshop, 1995. Lincoln University press, pp 1-33

Blagodatskaya E, Kuzyakov Y (2013) Active microorganisms in soil: critical review of estimation criteria and approaches. Soil 
Biol Biochem 67:192-211. https://doi.org/10.1016/j. soilbio.2013.08.024

Blagodatskaya YV, Anan'yeva ND, Myakshina TN (1996) Description of a soil microbe community in terms of metabolic quotient. Eurasian Soil Sci 28:86-95

Bosatta E, Ågren GI (1999) Soil organic matter quality interpreted thermodynamically. Soil Biol Biochem 31:1889-1891

Bradford MA, Ciska GF, Bonis A et al (2017) A test of the hierarchical model of litter decomposition. Nat Ecol Evol 1: 1836-1845. https://doi.org/10.1038/s41559-017-0367-4

Buurman P, Roscoe R (2011) Different chemical composition of free light, occluded light and extractable SOM fractions in soils of Cerrado and tilled and untilled fields, Minas Gerais, Brazil: a pyrolysis-GC/MS study. Eur J Soil Sci 62:253-266

Buurman P, Van Bergen PF, Jongmans AG et al (2005) Spatial and temporal variation in podzol organic matter studied by pyrolysis-gas chromatography/mass spectrometry and micromorphology. Eur J Soil Sci 56:253-270. https://doi. org/10.1111/j.1365-2389.2004.00662.x

Chapman SB (1971) A simple conductimetric soil respirometer for field use. Oikos 22:348-353

Chefetz B, Tarchitzky J, Deshmukh AP, Hatcher PG, Chen Y (2002) Structural characterization of soil organic matter and humic acids in particle-size fractions of an agricultural soil. Soil Sci Soc Am 66:129-141. https://doi.org/10.2136 /sssaj2002.0129

Ciais P, Sabine C, Bala G, et al (2014) Carbon and other biogeochemical cycles. In: climate change 2013: the physical science basis. Contribution of working group I to the fifth assessment report of the intergovernmental panel on climate change. Cambridge University press, pp 465-570

Conant RT, Ryan MG, Ågren GI, Birge HE, Davidson EA, Eliasson PE, Evans SE, Frey SD, Giardina CP, Hopkins FM, Hyvönen R, Kirschbaum MUF, Lavallee JM, Leifeld J, Parton WJ, Megan Steinweg J, Wallenstein MD, Martin Wetterstedt JÅ, Bradford MA (2011) Temperature and soil organic matter decomposition rates - synthesis of current knowledge and a way forward. Glob Chang Biol 17:33923404. https://doi.org/10.1111/j.1365-2486.2011.02496.x

Conen F, Leifeld J, Seth B, Alewell C (2006) Warming mobilises young and old soil carbon equally

Cotrufo MF, Wallenstein MD, Boot CM (2013) The microbial efficiency-matrix stabilization ( MEMS ) framework integrates plant litter decomposition with soil organic matter stabilization : do labile plant inputs form stable soil organic matter ? 988-995. doi: https://doi.org/10.1111/gcb.12113

Davidson EA, Janssens IA (2006) Temperature sensitivity of soil carbon decomposition and feedbacks to climate change. Nature 440:165-173. https://doi.org/10.1038/nature04514

Ekblad A, Nordgren A (2002) Is growth of soil microorganisms in boreal forests limited by carbon or nitrogen availability? Plant Soil 242:115-122. https://doi.org/10.1023 la:1019698108838

Erhagen B, Öquist M, Sparrman T, Haei M, Ilstedt U, Hedenström M, Schleucher J, Nilsson MB (2013) Temperature response of litter and soil organic matter decomposition is determined by chemical composition of organic material. Glob Chang Biol 19:3858-3871. https://doi.org/10.1111/gcb.12342

Erhagen B, Ilstedt U, Nilsson MB (2015) Temperature sensitivity of heterotrophic soil $\mathrm{CO} 2$ production increases with increasing carbon substrate uptake rate. Soil Biol Biochem 80:45-52. https://doi.org/10.1016/j.soilbio.2014.09.021

Eriksson L, Johansson E, Kettaneh-Wold N, Wold S (2001) Multiand megavariate data analysis: principles and applications. Umetrics

Fabbri D, Adamiano A, Falini G, de Marco R, Mancini I (2012) Analytical pyrolysis of dipeptides containing proline and amino acids with polar side chains. Novel 2,5diketopiperazine markers in the pyrolysates of proteins. $\mathrm{J}$ Anal Appl Pyrolysis 95:145-155. https://doi.org/10.1016/j. jaap.2012.02.001

Fang C, Smith P, Moncrieff JB, Smith JU (2005) Similar response of labile and resistant soil organic matter pools to changes in temperature. Nature 433:57-59

Fierer N, Craine J, Mclauchlan K, Schimel J (2005) Litter quality and the temperature sensitivity of decomposition. Ecology 86(2):320-326

Gerber L, Eliasson M, Trygg J, Moritz T, Sundberg B (2012) Multivariate curve resolution provides a high-throughput data processing pipeline for pyrolysis-gas chromatography/ mass spectrometry. J Anal Appl Pyrolysis 95:95-100. https://doi.org/10.1016/j.jaap.2012.01.011

Gleixner G, Bol R, Balesdent J (1999) Molecular insight into soil carbon turnover. Rapid Commun Mass Spectrom 13:12781283

Hajje N, Jaffé R (2006) Molecular characterization of Cladium peat from the Florida Everglades: biomarker associations with humic fractions. Hydrobiologia 569:99-112. https://doi.org/10.1007/s10750-006-0125-0

Hedges JI, Mann DC (1979) The characterization of plant tissues by their lignin oxidation products. Geochim Cosmochim Acta 43:1803-1807

Helfrich M, Ludwig B, Buurman P, Flessa H (2006) Effect of land use on the composition of soil organic matter in density and aggregate fractions as revealed by solid-state13C NMR spectroscopy. Geoderma 136:331-341. https://doi.org/10.1016/j. geoderma.2006.03.048

Hilli S, Stark S, Willför S, Smeds A, Reunanen M, Hautajärvi R (2012) Geoderma what is the composition of AIR ? Pyrolysis-GC - MS characterization of acid-insoluble residue from fresh litter and organic horizons under boreal forests in southern Finland 180:63-72. https://doi.org/10.1016/j. geoderma.2012.02.010

Hobbie SE, Reich PB, Oleksyn J, Ogdahl M, Zytkowiak R, Hale C, Karolewski P (2006) Tree species effects on decomposition and forest floor dynamics in a common garden. Ecology 87:2288-2297

Hyvönen R, Ågren GI, Linder S, Persson T, Cotrufo MF, Ekblad A, Freeman M, Grelle A, Janssens IA, Jarvis PG, Kellomäki S, Lindroth A, Loustau D, Lundmark T, Norby RJ, Oren R, Pilegaard K, Ryan MG, Sigurdsson BD, Strömgren M, van Oijen M, Wallin G (2007) The likely impact of elevated $[\mathrm{CO} 2]$, nitrogen deposition, increased temperature and management on carbon sequestration in temperate and boreal forest ecosystems: a literature review. New Phytol 173:463480. https://doi.org/10.1111/j.1469-8137.2007.01967.x

Ilstedt U, Nordgren A, Malmer A (2000) Optimum soil water for soil respiration before and after amendment with glucose in humid tropical acrisols and a boreal mor layer. Soil Biol Biochem 32:1591-1599. https://doi.org/10.1016/s00380717(00)00073-0 
Insam H, Domsch KH (1988) Relationship between soil organic carbon and microbial biomass on chronosequences of reclamation sites. Microb Ecol 15:177-188. https://doi. org/10.1007/BF02011711

Jonsson P, Johansson AI, Gullberg J, Trygg J, A J, Grung B, Marklund S, Sjöström M, Antti H, Moritz T (2005) Highthroughput data analysis for detecting and identifying differences between samples in GC/MS-based metabolomic analyses. Anal Chem 77:5635-5642. https://doi.org/10.1021 /ac050601e

Kane ES, Valentine DW, Schuur EAG, Dutta K (2005) Soil carbon stabilization along climate and stand productivity gradients in black spruce forests of interior Alaska 1. 2129:2118-2129. https://doi.org/10.1139/X05-093

Kanerva S, Smolander A (2007) Microbial activities in forest floor layers under silver birch, Norway spruce and scots pine. Soil Biol Biochem 39:1459-1467

Kanerva S, Kitunen V, Loponen J (2008) Phenolic compounds and terpenes in soil organic horizon layers under silver birch. Norway spruce and Scots pine 44:547-556. https://doi. org/10.1007/s00374-007-0234-6

Karhu K, Fritze H, Tuomi M, Vanhala P, Spetz P, Kitunen V, Liski J (2010) Temperature sensitivity of organic matter decomposition in two boreal forest soil profiles. Soil Biol Biochem 42: 72-82. https://doi.org/10.1016/j.soilbio.2009.10.002

Karjalainen EJ (1989) The spectrum reconstruction problem: use of alternating regression for unexpected spectral components in two-dimensional spectroscopies. Chemom Intell Lab Syst 7:31-38. https://doi.org/10.1016/0169-7439(89)80109-1

Kelleher BP, Simpson AJ (2006) Humic substances in soils: are they really chemically distinct? Environ Sci Technol 40: 4605-4611

Kleber M, Johnson MG (2010) Advances in Understanding the Molecular Structure of Soil Organic Matter. In: Advances in understanding the molecular structure of soil organic matter : implications for interactions in the environment, 1 st edn. Elsevier Inc.

Kögel I, Hempfling R, Zech W et al (1988) Chemical composition of the organic matter in forest soils: 1. Forest litter. Soil Sci 146:124-136

Kohl L, Philben M, Edwards KA, Podrebarac FA, Warren J, Ziegler SE (2018) The origin of soil organic matter controls its composition and bioreactivity across a Mesic boreal forest latitudinal gradient. Glob Chang Biol 24:e458-e473. https://doi.org/10.1111/gcb.13887

Lehmann J, Kleber M (2015) The contentious nature of soil organic matter. Nature 528:60-68. https://doi.org/10.1038 /nature 16069

Leifeld J, Fuhrer J (2005) The temperature response of CO 2 production from bulk soils and soil fractions is related to soil organic matter quality. Biogeochemistry 75:433-453

Liski J, Ilvesniemi H, Mäkelä A, Westman CJ (1999) $\mathrm{CO}_{2}$ emissions from soil in response to climatic warming are overestimated: the decomposition of old soil organic matter is tolerant of temperature. Ambio:171-174

Maaroufi NI, Nordin A, Palmqvist K, Gundale MJ (2017) Nitrogen enrichment impacts on boreal litter decomposition are driven by changes in soil microbiota rather than litter quality. Sci Rep 7:4083
Mackenzie AS, Brassell SC, Eglinton G, Maxwell JR (1982) Chemical fossils: the geological fate of steroids. Science 217(80):491-504

Marín-Spiotta E, Gruley KE, Crawford J, Atkinson EE, Miesel JR, Greene S, Cardona-Correa C, Spencer RGM (2014) Paradigm shifts in soil organic matter research affect interpretations of aquatic carbon cycling: transcending disciplinary and ecosystem boundaries. Biogeochemistry 117:279297

Melillo JM, Aber JD, Muratore JF (1982) Nitrogen and lignin control of hardwood leaf litter decomposition dynamics stable. Ecology 63:621-626. URL: http://www.jstor. org/stable/1936780. Accessed 14 March 2018

Melillo JM, Steudler PA, Aber JD et al (2002) Soil warming and carbon-cycle feedbacks to the climate system. Science 298(80):2173-2176

Micić V, Kruge MA, Köster J, Hofmann T (2011) Natural, anthropogenic and fossil organic matter in river sediments and suspended particulate matter: a multi-molecular marker approach. Sci Total Environ 409:905-919. https://doi. org/10.1016/j.scitotenv.2010.11.009

Mueller KE, Hobbie SE, Chorover J, Reich PB (2015) Effects of litter traits, soil biota, and soil chemistry on soil carbon stocks at a common garden with 14 tree species. doi: https://doi.org/10.1007/s10533-015-0083-6

Naafs DFW, Van Bergen PF, De Jong MA, Oonincx A, De Leeuw JW (2004) Total lipid extracts from characteristic soil horizons in a podzol profile:657-669. https://doi.org/10.1111 j.1365-2389.2004.00633.x

Nierop KGJ, Van Lagen B, Buurman P (2001) Composition of plant tissues and soil organic matter in the first stages of a vegetation succession. Geoderma 100:1-24. https://doi. org/10.1016/S0016-7061(00)00078-1

Nordgren A (1988) Apparatus for the continuous, long-term monitoring of soil respiration rate in large numbers of samples. Soil Biol Biochem 20:955-957. https://doi.org/10.1016 /0038-0717(88)90110-1

Olsson BA, Hansson K, Persson T, Beuker E, Helmisaari HS (2012) Heterotrophic respiration and nitrogen mineralisation in soils of Norway spruce, scots pine and silver birch stands in contrasting climates. For Ecol Manag 269:197-205

Öquist MG, Sparrman T, Klemedtsson L et al (2009) Water availability controls microbial temperature responses in frozen soil CO2 production. Glob Chang Biol 15:2715-2722. https://doi.org/10.1111/j.1365-2486.2009.01898.x

Öquist MG, Erhagen B, Haei M, Sparrman T, Ilstedt U, Schleucher J, Nilsson MB (2016) The effect of temperature and substrate quality on the carbon use efficiency of saprotrophic decomposition. Plant Soil 414:113-125. https://doi.org/10.1007/s11104-016-3104-x

Peulvé S, Sicre M-A, Saliot A, de Leeuw JW, Baas M (1996) Molecular characterisation of suspended and sedimentary organic matter in an Arctic delta. Limnol Oceanogr 41:488497

Preston C, Trofymow J, \{the Canadian Intersite Decomposition Experiment Working Group (2000) Variability in litter quality and its relationship to litter decay in Canadian forests. Can J Bot 78:1269-1287. https://doi.org/10.1139/cjb-78-10-1269

Pries CEH, Castanha C, Porras RC (2017) Torn MS. The wholesoil carbon flux in response to warming 1423:1420-1423 
Quideau SA, Chadwick OA, Trumbore SE, Johnson-Maynard JL, Graham RC, Anderson MA (2001) Vegetation control on soil organic matter dynamics. Org Geochem 32:247-252. https://doi.org/10.1016/S0146-6380(00)00171-6

Saiz-Jimenez C, De Leeuw JW (1986) Lignin pyrolysis products: their structures and their significance as biomarkers. Org Geochem 10:869-876

Schellekens J, Buurman P, Pontevedra-Pombal X (2009) Selecting parameters for the environmental interpretation of peat molecular chemistry-a pyrolysis-GC/MS study. Org Geochem 40:678-691

Schmidt MWI, Torn MS, Abiven S, Dittmar T, Guggenberger G, Janssens IA, Kleber M, Kögel-Knabner I, Lehmann J, Manning DAC, Nannipieri P, Rasse DP, Weiner S, Trumbore SE (2011) Persistence of soil organic matter as an ecosystem property. Nature 478:49-56. https://doi. org/10.1038/nature 10386

Schnitzer M, McArthur DFE, Schulten HR et al (2006) Long-term cultivation effects on the quantity and quality of organic matter in selected Canadian prairie soils. Geoderma 130: 141-156. https://doi.org/10.1016/j.geoderma.2005.01.021

Schulten HR, Leinweber P, Reuter G (1992) Initial formation of soil organic matter from grass residues in a long-term experiment. Biol Fertil Soils 14:237-245. https://doi.org/10.1007 /BF00395458

Sierra CA (2012) Temperature sensitivity of organic matter decomposition in the Arrhenius equation : some theoretical considerations. 1-15. https://doi.org/10.1007/s10533-0119596-9

Simpson MJ, Simpson AJ (2012) The chemical ecology of soil organic matter molecular constituents. J Chem Ecol 38:768784. https://doi.org/10.1007/s10886-012-0122-x

Smolander A, Loponen J, Suominen K, Kitunen V (2005) Organic matter characteristics and $\mathrm{C}$ and $\mathrm{N}$ transformations in the humus layer under two tree species, Betula pendula and Picea abies. Soil Biol Biochem 37:1309-1318

Soil Survey Staff (2003) Keys to soil taxonomy. Agriculture 153: 332

Sollins P, Homann P, Caldwell B a. (1996) Stabilization and destabilization of soil organic matter1.Pdf. Geoderma 74: 65-105. https://doi.org/10.1016/S0016-7061(96)00036-5

Stark S, Hilli S, Willför A, Smeds AI, Reunanen M, Penttinen M (2012) Composition of lipophilic compounds and carbohydrates in the accumulated plant litter and soil organic matter in boreal forests:65-74. https://doi.org/10.1111/j.13652389.2011.01411.x

Stenberg B, Johansson M, Pell M, Sjödahl-Svensson K, Stenström J, Torstensson L (1998) Microbial biomass and activities in soil as affected by frozen and cold storage. Soil Biol Biochem 30:393-402. https://doi.org/10.1016/s0038-0717(97)001259

Sutton R, Sposito G (2005) Molecular structure in soil humic substances: the new view. Environ Sci Technol 39:90099015

Tarnocai C, Canadell JG, Schuur EAG et al (2009) Soil organic carbon pools in the northern circumpolar permafrost region.
Glob Biogeochem Cycles 23:1-11. https://doi.org/10.1029 /2008GB003327

Tilston EL, Sparrman T, Öquist MG (2010) Unfrozen water content moderates temperature dependence of sub-zero microbial respiration. Soil Biol Biochem 42:1396-1407. https://doi. org/10.1016/j.soilbio.2010.04.018

Tolu J, Gerber L, Boily JF, Bindler R (2015) High-throughput characterization of sediment organic matter by pyrolysis-gas chromatography/mass spectrometry and multivariate curve resolution: a promising analytical tool in (paleo)limnology. Anal Chim Acta 880:93-102. https://doi.org/10.1016/j. aca.2015.03.043

Trumbore S (2000) Age of soil organic matter and soil respiration: radiocarbon constraints on belowground $\mathrm{C}$ dynamics. Ecol Appl 10:399-411

Vancampenhout K, Wouters K, De Vos B et al (2009) Differences in chemical composition of soil organic matter in natural ecosystems from different climatic regions-a pyrolysis-GC/ MS study. Soil Biol Biochem 41:568-579

Vance ED, Chapin FS (2001) Substrate limitations to microbial activity in taiga forest floors. Soil Biol Biochem 33:173-188. https://doi.org/10.1016/S0038-0717(00)00127-9

Vesterdal L, Schmidt IK, Callesen I, Nilsson LO, Gundersen P (2008) Carbon and nitrogen in forest floor and mineral soil under six common European tree species. For Ecol Manag 255:35-48. https://doi.org/10.1016/j.foreco.2007.08.015

Vesterdal L, Elberling B, Christiansen JR, Callesen I, Schmidt IK (2012) Soil respiration and rates of soil carbon turnover differ among six common European tree species. For Ecol Manag 264:185-196. https://doi.org/10.1016/j.foreco.2011.10.009

Vesterdal L, Clarke N, Sigurdsson BD, Gundersen P (2013) Do tree species influence soil carbon stocks in temperate and boreal forests? For Ecol Manag 309:4-18. https://doi. org/10.1016/j.foreco.2013.01.017

Waksman SA (1936) Humus origin, chemical composition, and importance in nature. Soil Sci 41:395. https://doi.org/10.1097 /00010694-193605000-00010

Wardle DA, Ghani A (2018) A tale of two theories, a chronosequence and a bioindicator of soil quality. Soil Biol Biochem 121:A3-A7. https://doi.org/10.1016/j. soilbio.2018.01.005

Wardle DA, Parkinson D (1990) Interactions between microclimate variables and the soil microbial biomass. Biol Fertil Soils 9:273-280

Werner RA, Bruch BA, Brand WA (1999) ConFlo III-AnInterface for high precision d $13 \mathrm{C}$ and d $15 \mathrm{~N}$ analysis with an extended dynamic range. Rapid Commun Mass Spectrom 13:1237-1241

Publisher's note Springer Nature remains neutral with regard to jurisdictional claims in published maps and institutional affiliations. 